\title{
US consumers' acceptance of hand-produced apparel from India
}

\author{
Nancy J Miller*, Mary A Littrell \& J eanne M Link
}

\begin{abstract}
OPSOMMING
Vervaardigers van kleding moet die ontwerpelemente van verwagte veranderings in die mode korrek vertolk om seker te maak dat hulle die aandag van verbruikers trek en op dié wyse verkope genereer.
\end{abstract}

Die begrippe wat Rogers (1962) in sy teorie oor die verspreiding van innoverende ontwerpe by wyse van kommunikasie noem, is bestudeer om te bepaal in watter mate hierdie teorie ' $n$ teikengroep Amerikaanse verbruikers se aanvaarding van kultureel geïnspireerde kleding uit Indië onderskryf. Die hipoteses vir hierdie navorsing berus op Rogers (1962) se teorie en is empiries getoets vir inligting oor ' $n$ klein kledingvervaardiger en om die toepassing van die kenmerke van verspreiding in die tekstiel- en kledingdissiplines uit te brei. Data is by 164 damestudente aan ' $n$ universiteit ingesamel. ' $n$ Vyfpunt- bipolêre skaal is gebruik om ses modelkledingstukke (langbroeke en rompe) ten opsigte van kompleksiteit, familiariteit en aanvaarding te beoordeel. Die kenmerke van die kledingstukke het kleur, konstruksie, kleedstof, sluiting en profiel ingesluit.

Die navorsingsbevindinge het Rogers (1962) se teorie gedeeltelik bevestig. Kledingvervaardigers behoort dus kennis te neem dat sommige ontwerpelemente groter potensiaal as ander het wanneer dit by produkontwikkeling en verbruikersaanvaarding kom. Vertroudheid met ' $n$ kledingstuk se kleur en profiel het die grootste invloed op die algemene aanvaarding van die kledingstuk uitgeoefen. Bykomende teoretiese verkenning asook navorsing oor die bemarking van handwerkondernemings is voorgestel.

\section{- NJ Miller* \\ - MA Littrell \\ - JM Link \\ Department of Textiles and Clothing, \\ lowa State University}

\section{Acknowledgment:}

This study was made possible by funding from the Family and Consumer Sciences Research Institute and the College of Family and Consumer Sciences, lowa State University, Ames, lowa 50011. The authors also wish to thank MarketPlace: Handwork of India, and the faculties and students who participated in the study at lowa State University, Washington State University, University of Arizona, University of Delaware, and Louisiana State University.

\section{INTRODUCTION}

Consumer decision is influenced by many variables. Howard and Sheth (1969) considered this decision process to involve both a perceptual subsystem involving attention to information, and a learning subsystem for processing information. Marketing practitioners should understand which information consumers require and use when they make purchasing decisions. Considerable time and effort are devoted to identifying and developing product attributes that are likely to hold consumers' attention and ultimately persuade them to accept and/or purchase a product.

Developing new or innovative attributes for products influenced by fashion is given a high priority. Marketers of fashion strive for originality, or the perception of newness, as a means of increasing their market share. Foreign companies may utilise differences in cultural taste and aesthetics to suggest newness or innovativeness in garment designs destined for the US. MarketPlace: Handwork of India is one such marketer who, in an effort to provide employment for textile artisans in underdeveloped areas of India, has attempted to incorporate Western design elements in culturally embedded fabric techniques, embellishments and garment forms of India.

MarketPlace is an example of small entrepreneurial artisan enterprises located in many parts of the lessdeveloped world. With goals beyond that of income generation, these businesses work to achieve longterm sustainability and worker empowerment for individuals, households and communities. Central to the success of such businesses is the development of markets outside their communities and regions. As artisans shift towards market diversification, they face many challenges related to production and marketing (Basu, 1995; Dickson \& Littrell, 1997; Herald, 1992; Littrell \& Dickson, 1998, 1999; Mikkelson et al, 1997; Morris, 1996; Nash, 1993; Page-Reeves, 1998; Tice, 1995). Aageson (1997), an international craftmarketing specialist, argues that building strong artisan enterprises requires investment in three critical areas, namely business skills; creativity in terms of innovative, market-driven product development; and marketing approaches for diverse patrons.

MarketPlace, a rapidly growing US importer and catalogue retailer, has had considerable success in marketing women's jacket and dress designs in the US. However, its skirt and pants designs produced in Mumbai were not well received. This company's market research suggests it also failed to capture the attention of college females between the ages of 18 and 
30 years. MarketPlace designers need market-based research to position their skirts and pants designs to attract the attention and acceptance of this market segment.

MarketPlace considers product development to be a proactive, collaborative venture between designers and artisans and US consumers. In the Global Dialogue section of each catalogue, customers and artisans share insights about their lives on catalogue themes such as Celebrating Strong Women, Choices and Changes, and The Work of Our Hands (Littrell \& Dickson, 1999). MarketPlace also collaborates with researchers in building a database to which artisans may refer when design decisions have to be made.

The diffusion process is a widely studied social phenomenon with numerous applications in education, geography, agriculture and business (Barnett, 1953; Bass \& King, 1968; Katz et al, 1963; Lionberger, 1960; Mahajan \& Peterson, 1985). Rogers' (1962) communication-based theory on the diffusion of innovation has been widely studied (Forsythe et al, 1991; Grindereng, 1967; Mason \& Bellenger, 1973-74; Sproles \& King, 1973; Workman \& Johnson, 1993). This theory describes the communication or spreading of a given innovation among a selected set of potential adopters in a social system. Rogers (1995) suggested that not all innovations were equivalent and consequently proposed five specific attributes to be examined in explaining an innovation's anticipated rate of adoption. These attributes operated in different directions and at different levels, some more dominant than others. Theoretically, by determining an attribute's potential influence on an innovation, the rate and level of adoption could be predicted.

\section{DIFFUSION THEORY}

Rogers' diffusion theory (1995), which has been applied to explain the movement of fashion products or services from inception to mass adoption, begins with the introduction of a new idea or product called an innovation (Sproles, 1979). In fashion, innovation is frequently specific garment design characteristics that are perceived to be new or relatively unknown.

As fashion successfully diffuses, its acceptance varies across adopter types. What was early in the diffusion process perceived to possess the relative advantage of exclusivity, is later worn by the masses and no longer favourable to the innovator group (Berg, 1973). Familiarity, the ingredient that enhances the adoption of fashion, is thus also responsible for its demise. Hurlock (1929) and Bull (1975) believe that fashion innovations are motivated by a human desire for change or variety. They maintain that people become bored with the familiar and that innovations are adopted because fashion innovators desire variety or change. Workman and Johnson (1993) supported these hypotheses in their study of fashion opinion leaders.
According to Rogers' (1995:250-251) communicationbased version of diffusion theory, an innovation's level and rate of acceptance are influenced by five attributes, namely relative advantage, compatibility, complexity, trialability and observability. Briefly, "relative advantage" refers to the new product's improvement or differentiation compared to the old product. In fashion this advantage may be the perceived exclusivity when a new fashion product is displayed.

The compatibility attribute refers to the degree to which an innovation coexists or coordinates with previously accepted ideas or products. Fashion innovations that mix or perform well in terms of consumers' existing wardrobes possess a high degree of compatibility. Compatibility also pertains to the extent to which the garment or its qualities correspond with the consumer's management of his or her own image (Kaiser et al, 1995).

Rogers' third attribute, namely complexity, refers to the supposed intricacy or difficulty of the innovation. A very complex fashion may cause consumers to have difficulty in learning the mechanics involved in adopting the innovation to go with existing garments. Less complex fashions require minimal learning experience and are more likely to be accepted. Rogers (1995) stated that the perceived complexity of an innovation is negatively related to its rate of adoption.

The attribute of trialability is the extent to which an innovation can be tested or experienced on a small scale. As fashion retailers do not offer trial runs on items of clothing, there are perceived risks in purchasing fashion items. Consumers may look for ways to test the innovation on a limited basis, perhaps by purchasing a less expensive version of the innovation or by simulating the innovation on a computer by using software programs designed to try different hairstyles or swimsuit styles. Repeated exposure to the innovation increases its familiarity and simultaneously reduces the perceived risk (trialability) and increases its acceptability.

Rogers' fifth innovation attribute is observability or communicability. Visible innovations are easily communicated and therefore quickly adopted and legitimised. A fashion innovation seen to be worn by celebrities and peer group members will enhance the innovation's rate and level of acceptance. The innovative communicator is both an early buyer and an opinion leader who acts as a change agent in the diffusion process. This is critical to the movement of fashion (Goldsmith et al, 1996; King, 1965; Sproles, 1979; Summers, 1970).

Though not detailed in Rogers' theory of diffusion, there is support for Robinson's (1967) and Usher's (1954) beliefs that familiar elements in an innovation aid the adoption process. Familiarity is inherent in Rogers' characteristics of relative advantage, compatibility and observability/communicability. Familiarity provides the basis for comparing previously adopted products with new products and the vocabu- 
lary for communicating similarities and differences. Inversely, the complexity characteristic often requires additional learning because of the unfamiliar aspects of the innovation. Rogers (1995:207) refers to familiarity as "awareness knowledge" that is communicated through interpersonal or mass media channels.

Rogers' diffusion attributes were partially examined for their power to influence the acceptance of an innovation in a targeted segment of the US market. The fashion innovation under investigation was the skirt and pants designs inspired and produced by MarketPlace artisans in India. Behling (1992) chronicled 35 years of diffusion research regarding fashion adoption and assessed the need for empirical investigation of fashion diffusion. Despite the widespread application of diffusion models, Peterson and Mahajan (1978) found few scientists attempted to use existing models in testing innovations relative to their specific disciplines. Finding, or failing to find, support for Rogers hypotheses, were intended to offer both important scholarly implications for testing the diffusion theory and practical product development knowledge for MarketPlace.

\section{US CONSUMER ACCEPTANCE OF CULTURALLY EMBEDDED APPAREL}

US consumers favour innovation, as is evidenced by their fascination with novel products and by advertisers' emphasis on "new". Marketers constantly try to differentiate their products via innovation in an effort to increase their market share. However, it may be difficult to balance newness with the familiar. A unique apparel product may be judged to have formidable complexity or poor communicability characteristics. All foreign manufacturers who wish to introduce culturally embedded products to the US market face this dilemma. How do they establish a market niche with their culturally diverse products? Which elements of the producer culture should be retained and presented as "original", and which elements of the consumer culture should be incorporated as familiar? Chowdhary and Dickey (1988) found in their research among college women in India that the fashion adoption process is culture-bound. Yet Kean (1997) maintains that the fashion system is increasingly global, meaning that only minor product changes are needed to satisfy a nation's tastes.

Conducting research among potential customers of MarketPlace provided an opportunity to explore how details of culturally embedded apparel cross cultures in fashion diffusion. This type of product development information is important to a company like MarketPlace who wants to provide sustained work and income not just for the tailors and sewers who create the garment forms, but also for the artisans involved in fabric dyeing and embroidered surface embellishments. These research findings have implications beyond MarketPlace as business parallels found in numerous other entrepreneurial enterprises hope to cross cultural boundaries with their own versions of culturally embedded apparel.

The researchers attempted to empower MarketPlace by way of empirical research into targeted consumers' judgments about their skirt and pants designs. They began by referring to previous inductive research in which mail-order customers were asked to identify attributes that were important to them in making purchasing decisions about women's apparel (AbrahamMurali \& Littrell, 1995). The consumers were older females $(\underline{M}=40)$ who offered observable, compositional garment attributes on being presented with both photographs and actual garments. Thirty-seven per cent of the themes discussed during focus-group sessions were devoted to physical appearance attributes such as styling, fabric, colour and construction.

Based on Abraham-Murali and Littrell's (1995) findings, it was deemed important to measure the consumers' responses to the colour, construction, fabric and silhouette characteristics of the India-inspired garments. The fastening method was also studied as the manufacturer's current production and importing strategies permitted only elastic, drawstring or fabric ties to fasten the garments.

This research was summarised by assessing the targeted market's perceptions of the complexity and familiarity of the India-inspired garments. These two diffusion attributes were measured to determine which attributes had a significant influence on the consumer's decision to accept the garments. An applied outcome was to identify a basis for designing and positioning the MarketPlace garments to ensure greater potential for adoption in the US.

\section{METHODOLOGY}

\section{Hypotheses}

The main objective of this research into the attributes of innovation was to facilitate the prediction of a future rate of adoption or acceptance. Often the dependent variable is measured in the recent past, and the independent variables are a measurement of the present. For this reason an attempt was made to conduct a forward-looking investigation, measuring the current acceptance of consumers and the likelihood of their purchasing the fashion items. The following hypotheses were tested:

$\mathrm{H} 1$ US female, college-aged consumers can evaluate and differentiate the familiarity and complexity qualities of India-inspired garments:
Colour complexity

Construction complexity

Fabric complexity

Fastener complexity

Silhouette complexity
Colour familiarity

\section{Construction familiarity}

Fabric familiarity

Fastener familiarity

Silhouette familiarity 
H2 US female, college-aged consumers' acceptance of India-inspired garments will be influenced by the following perceived attributes:

\section{Complexity \\ Familiarity}

\section{Development of visual stimuli, an instrument and procedure}

An important part of the instrument development process was the generation of accurate and representative apparel stimuli to measure consumer response. Studies of consumer preferences by DeLong et al (1993) and Holbrook (1983) examined artificial stimuli exemplified by photographs versus the use of the products. The findings suggested that when real products are used, the respondents tended to base their evaluations on tactile rather than visual factors. Photographs or slides have been suggested as a valid method for discerning consumer perceptions of apparel (Whisney et al, 1979; Winakor \& Goings, 1973).

Lennon and Burns (1993) maintain that stimulus sampling could introduce statistical error in the research. Attempts were therefore made to control extraneous factors during the presentation of stimuli at universities. Stimuli presented as slides were deemed the best solution to controlling variability in garment conditions, for example wrinkles and drape as well as fit. Minshall (1994) suggested that apparel studies that focused on everyday dress selected stimuli that were relevant to the respondents' perceptions of everyday dress, thus allowing concentration on the properties of garments and preferences. MarketPlace garments were consequently presented in slide format congruent with the presentation formats in US apparel catalogues for everyday dress.

Existing MarketPlace skirt and pants styles were not deemed usable because the company recognised that these garments were not acceptable to US consumers in the targeted market segment. Stimulus development therefore began with designers for the US consumer culture, examining traditional garments from India as well as current MarketPlace designs. The US designers were members of the target market segment, namely two females in the 18 to 30 -year age range who were graduate and undergraduate students in a textiles and design programme.

Keeping in mind the essential garment elements traditionally associated with MarketPlace designs, and in view of the technological and import limitations that currently apply to the manufacturer, the design team assembled ideation boards for ten skirt and ten pants designs. These full-colour ideation boards exhibited a mix of current US pants and skirt designs from fashion magazines, catalogues and advertisements, the design team's fashion sketches, fabric samples provided by MarketPlace, and computer-aided design renditions of these fabrics in a proposed garment.

The 20 ideation boards were sent to the MarketPlace head designer in India with a request to consider the ideas and to create three new pants garments and three new skirt garments for testing on a targeted US consumer group. Thus, though inspired by designers in the consumer culture, the final six garments were the products of MarketPlace artisans, created by MarketPlace employees, featuring their fabrics, surface embellishments and sewing processes. None of the final six garments was a copy of a US-suggested design, and each garment was actually a mix of two or three designs from the ideation boards.

The six designs represented MarketPlace's "signature look" which is culturally embedded in Indian aesthetics, forms and production techniques (see Table 1). Each MarketPlace garment begins with bold, handblock-printed fabrics that are intensely coloured and visually unique. The embroidered surface embellishment follows the lines of fabric motifs to facilitate application by the artisans. Although the embellishment is visually striking and sometimes appears complicated, the needlework stitches remain simple so that new artisans may learn the techniques in a short time. Maintaining an embroidery-intense clothing line is central to the MarketPlace mission. A product development formula to provide employment to three embroiderers for each sewer offers work to a maximum number of artisans.

The six garments were photographed on a Caucasian female model of 21 years old to reduce the number of confounding variables in the visual stimuli. The model wore the same black knitted top with each garment. Stimuli development research by Whisney et al (1979) suggested that consumers could more easily relate photographed garments to newly acquired garments.

Three versions of the photographs were pilot-tested with six textiles and clothing faculty members to ascertain which version best represented the garment on a body form. The first version contained a full view of the model. The second version was similar to the first but with the model's head in silhouette. The third version presented only a partial view of the model, from her ribcage to her feet. The pilot group agreed that the complete figure and face should be shown in detail and that a section of the fabric print and/or stitching should be enlarged and digitally inserted to provide additional clarity of MarketPlace's artistry.

A questionnaire was developed to measure consumers' responses to each garment. The questionnaire items provided an index of two diffusion characteristics (familiarity and complexity), potential adoption behaviour (acceptability), and general demographic information. Photographs of the six garments were made into slides and pilot-tested on a sample of the target population, namely 24 females of college age who enrolled for textiles and clothing courses. A set of procedures was established to enhance replication of the instrumentation process with five different college-age consumer groups across the US. Written instructions for data collection accompanied each set of slides and questionnaires. Cover letters informed 


\begin{tabular}{|c|c|c|c|c|c|c|c|}
\hline \multirow[t]{2}{*}{ 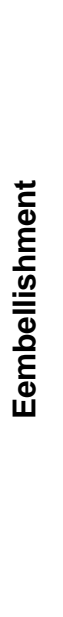 } & $\begin{array}{l}\bar{t} \\
\bar{\Sigma} \\
\Sigma\end{array}$ & 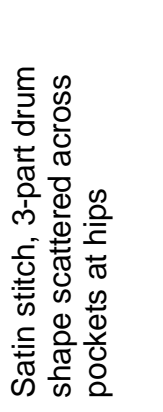 & 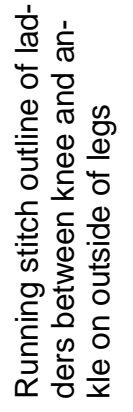 & 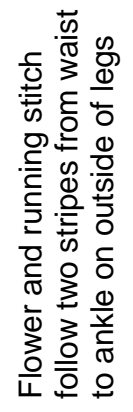 & & 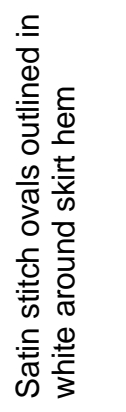 & \\
\hline & 흥 & 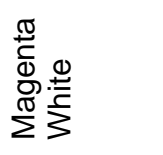 & $\stackrel{\frac{0}{3}}{\frac{.}{3}}$ & $\begin{array}{l}\stackrel{\pi}{ \pm} \\
\frac{0}{0} \\
\frac{\pi}{2}\end{array}$ & 造 & $\begin{array}{l}\frac{\tau}{0} \\
\frac{0}{\frac{0}{\pi}} \\
\frac{\pi}{2}\end{array}$ & ஜั \\
\hline \multicolumn{2}{|c|}{ 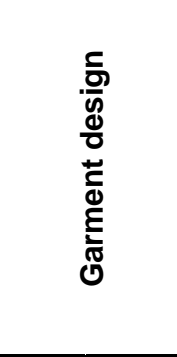 } & 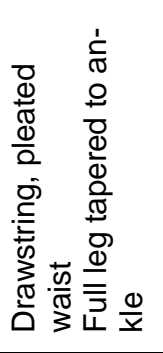 & 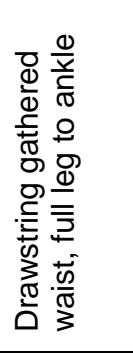 & 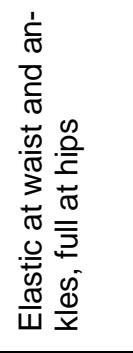 & 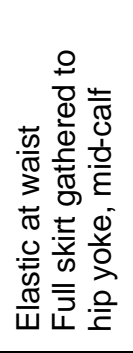 & 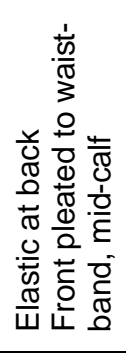 & 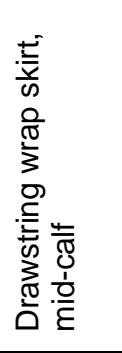 \\
\hline \multirow{3}{*}{ 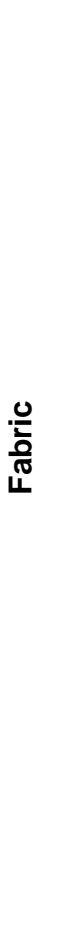 } & $\begin{array}{l}\bar{E} \\
\bar{\Sigma}\end{array}$ & 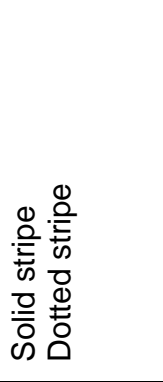 & 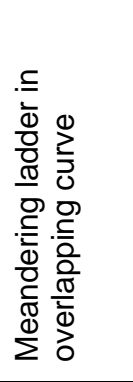 & 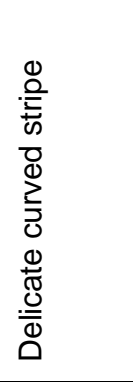 & 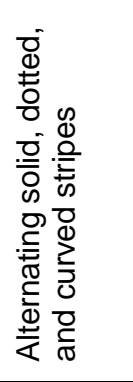 & 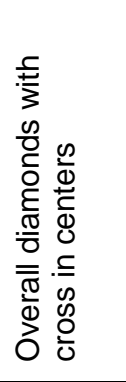 & 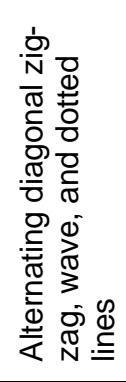 \\
\hline & 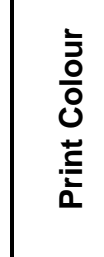 & 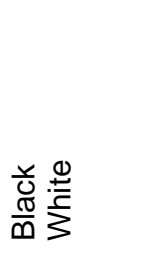 & $\underset{\substack{\text { Z } \\
z}}{>}$ & $\underset{\substack{\text { Z } \\
z}}{\overline{2}}$ & $\begin{array}{l}\frac{r}{0} \\
\frac{\pi}{0}\end{array}$ & $\begin{array}{l}\frac{r}{0} \\
\frac{\pi}{0}\end{array}$ & $\begin{array}{l}\bar{w} \\
\vec{\sim}\end{array}$ \\
\hline & 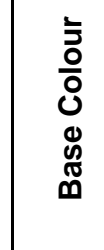 & 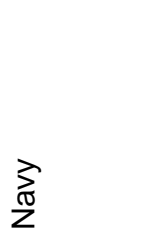 & $\begin{array}{l}\frac{0}{0} \\
\frac{2}{3} \\
\frac{0}{2}\end{array}$ & $\begin{array}{l}\frac{0}{2} \\
\frac{0}{0} \\
\frac{1}{0} \\
\frac{0}{0}\end{array}$ & $\begin{array}{l}\bar{\otimes} \\
\ddot{x}\end{array}$ & $\begin{array}{l}\mathscr{\mathscr { D }} \\
\stackrel{\mathscr{\Phi}}{\infty} \\
0\end{array}$ & 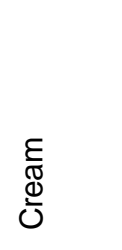 \\
\hline & 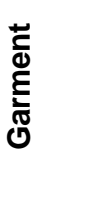 & 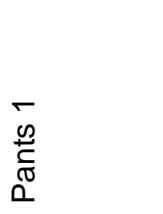 & 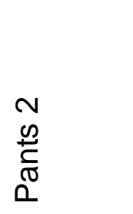 & $\begin{array}{l}\infty \\
0 \\
\stackrel{0}{T} \\
0 \\
0\end{array}$ & $\frac{\bar{E}}{\dot{v}}$ & 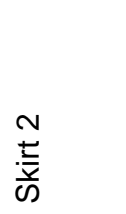 & $\frac{m}{\frac{m}{5}}$ \\
\hline
\end{tabular}


the students that participation was voluntary and that their responses would remain anonymous.

A set order was established for the slides, interspersing three pants styles with slides of the three skirt styles. The data were collected in university classroom settings. Each garment was projected individually and consumers responded to questionnaire items in connection with the particular slide. Consumers were asked to rate the familiarity and complexity of the garment characteristics of colour, construction, fabric, fastener and silhouette on a five-point bipolar scale. A rating of 1 indicated "unfamiliar" or "not complex", and a rating of 5 indicated "familiar" or "complex". Consumers were also asked to rate the overall acceptance of the skirt or pants designs on a five-point bipolar scale (1 indicating "not acceptable" and 5 indicating "acceptable"). The questionnaire demographic items related to age, years in school, and major subjects.

\section{Sample}

Data were collected from students who enrolled for textiles and clothing courses at five US universities. The sample consisted of 164 women between the ages of 17 and 31 . Most of the women in the sample (69\%) were between 20 and 22 years old. The typical participant could be described as a junior textiles and clothing student with proportionally more pants (63\%) than skirts $(30 \%)$ in her wardrobe.

The sample had limitations in terms of the generalisation of the findings, although it did reflect the desired characteristics of the manufacturer's potential target market. Research on fashion acceptance found that college campuses represent a good source of marketing information for adjusting marketing strategies and introducing more effective merchandise strategies (Behling, 1992; King \& Baumgarten, 1970; Mason \& Bellenger, 1973-74). The researchers in this exploratory study assumed that textiles and clothing students would be familiar with the terminology (eg silhouette and construction). Additional studies using the same stimuli on non-textiles and clothing students have been planned to examine potential response biases.

\section{Analyses and results}

Hypothesis 1 was tested by means of exploratory factor analysis to determine whether the consumer group could evaluate and differentiate the garment design qualities in terms of complexity and familiarity. The principal component factor analysis with varimax rotation generated a three-factor solution with all familiarity items loading on Factor 1 . The complexity items related to colour, construction and fabric loading on Factor 2, and the complexity items related to fastener and silhouette loading on Factor 3 (see Table 2).

Our finding supported Hypothesis 1 that design qualities related to complexity were evaluated and differentiated from design qualities related to familiarity.

Hypothesis 2 was tested by means of multiple regres- sion analyses (see Table 3). The dependent variable "acceptance" was derived from the sum of the scores for all six garments to generate a score for overall acceptance of MarketPlace's garments. As an independent variable, the diffusion attribute "complexity" was also a composite variable derived from consumers' responses to all six garments and the perceived complexity of the five design qualities. Similarly, the independent variable "familiarity" was derived from consumers' responses to all six garments and the perceived familiarity of the five design qualities.

The independent variables were entered in steps for each multiple regression analysis and the significance was set at $\leq, 05$. In testing Hypothesis 2, familiarity significantly influenced consumer acceptance $\left(R^{2}=\right.$ $0,24)$. The diffusion attribute of complexity did not significantly influence consumer acceptance with familiarity already in the equation. Hypothesis 2 was therefore only partially supported.

In determining which of the individual garment design qualities significantly influenced acceptability, all five garment qualities for complexity and all five garment qualities for familiarity were entered in steps for an additional multiple regression analysis (see Table 2). Total colour familiarity entered at the first step $\left(R^{2}=\right.$ $0,226)$, followed by total silhouette familiarity $\left(R^{2}\right.$ change $\left.=0,02\right)$ at Step 2 . No other garment qualities were significant for measuring either familiarity or complexity.

\section{DISCUSSION OF FINDINGS}

\section{Implications in terms of garment attributes and diffusion studies}

The findings offer empirical support for AbrahamMurali and Littrell's (1995) qualitative research grounded in consumers' vocabulary for their conceptualisation of apparel attributes. Several attributes from the researchers' composite list were tested on a younger segment of female consumers and were found to represent product characteristics that played a significant role in product evaluation and differentiation. The participants in the study were able to consider both the complexity and the familiarity of the five product elements of colour, construction, fabric, fastener and silhouette. The results suggest that familiarity with a garment's colour and silhouette has the greatest influence on overall acceptance. In other words, the more familiar the garment's colour and silhouette, the more likely the targeted consumer would accept the design and fit of the garment and purchase the garment. Eckman (1997) found similar levels of acceptance for garment silhouette in her study of men's tailored suits.

Partial support was found for the attributes Rogers' (1995) deemed necessary for innovation diffusion. Product complexity did not significantly influence consumers' acceptance or the likelihood of their purchasing a product. 
TABLE 2

FACTOR ANALYSIS OF GARMENT DESIGN QUALITIES

\begin{tabular}{|l|c|c|c|}
\hline \multicolumn{1}{|c|}{ Garment Design Qualities } & $\begin{array}{c}\text { Factor 1 } \\
\text { Familiarity }\end{array}$ & $\begin{array}{c}\text { Factor 2 } \\
\text { Complexity 1 }\end{array}$ & $\begin{array}{c}\text { Factor 3 } \\
\text { Complexity 2 }\end{array}$ \\
\hline Color Familiarity & 0.84 & & \\
Construction Familiarity & 0.71 & & \\
Fabric Familiarity & 0.79 & & \\
Fastener Familiarity & 0.79 & & \\
Silhouette Familiarity & 0.79 & 0.83 & \\
\hline Color Complexity & & 0.88 & \\
Construction Complexity & & 0.91 & 0.84 \\
Fabric Complexity & & & 0.83 \\
Fastener Complexity & 4.01 & 64.40 & 74.70 \\
Silhouette Complexity & 36.40 & & \\
\hline Eigenvalue & & & \\
Percent of Variance & & & \\
\hline
\end{tabular}

$\mathrm{N}=146$

TABLE 3

MULTIPLE REGRESSION ANALYSES OF GARMENT FAMILIARITY AND COMPLEXITY

\begin{tabular}{|c|c|c|c|c|c|c|c|}
\hline Hypotheses & $\begin{array}{c}\text { Dependent } \\
\text { Variable }\end{array}$ & $\begin{array}{l}\text { Independent } \\
\text { Variable }\end{array}$ & $B$ & t-value & Significance & $\mathbf{R}^{2}$ & $\begin{array}{c}\text { Change } \\
\text { In } R^{2}\end{array}$ \\
\hline $\mathrm{H}_{2}$ & $\begin{array}{l}\text { Acceptance } \\
\text { Acceptance }\end{array}$ & $\begin{array}{l}\text { Familiarity } \\
\text { Complexity } \\
\text { Familiarity: } \\
\text { Color } \\
\text { Silhouette } \\
\text { Construction } \\
\text { Fabric } \\
\text { Fastener } \\
\text { Complexity: } \\
\text { Color } \\
\text { Silhouette } \\
\text { Construction } \\
\text { Fabric } \\
\text { Fastener }\end{array}$ & $\begin{array}{l}.168 \\
.370 \\
\\
\\
.456 \\
.280 \\
.098 \\
.052 \\
.015 \\
\\
.080 \\
.007 \\
.048 \\
<.004 \\
.076\end{array}$ & $\begin{array}{c}6.792 \\
.503 \\
\\
\\
4.082 \\
2.166 \\
1.166 \\
.505 \\
.133 \\
\\
.956 \\
.092 \\
.609 \\
.005 \\
1.016\end{array}$ & $\begin{array}{c}<.001 \\
.618 \\
\\
\\
<.001 \\
.032 \\
.246 \\
.614 \\
.894 \\
\\
.341 \\
.927 \\
.543 \\
.996 \\
.311\end{array}$ & .243 & .243 \\
\hline
\end{tabular}

$\mathrm{N}=146$ 
This sample population in general did not rate the MarketPlace garments as very complex $(\underline{M}=104$ on a 32-177 point range), which should, according to Rogers' generalisation, enhance consumer acceptance. Strong support was found for Rogers' compatibility attribute and the familiarity concept, inherent in his discussion of awareness knowledge. These two garment attributes together accounted for $39 \%$ of the variance in the likelihood of the targeted consumers' purchasing MarketPlace garments. It should be noted, however, that the garments' complexity qualities were perceived to be in two separate groups, as indicated by the loading of garment complexity qualities on to two factors. One factor focused on colour, fabric and construction, and the other centred on garment silhouette and fasteners. This could be an area for future attribution and diffusion research.

Supporting previous MarketPlace analyses of dominant US consumer groups, the six garments were not highly acceptable to the college-age market segment $(\underline{M}=25,7$ on a 12 to 58 -point range). Neither were these garments highly familiar $(\underline{M}=115$ on a 42 to 183-point range), nor highly compatible with consumers' existing wardrobes ( $\underline{M}=9,7$ on a 6 to 24-point range).

In previous analyses of college students as fashion innovators, opinion leaders, innovative communicators and followers, Workman and Johnson (1993) found significant differences in students' sensation or variety-seeking scores. Of the 425 participants in this research, approximately $75 \%$ were fashion followers. Though neither sensation seeking nor innovativeness was measured in this study, the results suggest that too much variation from current skirt and pants fashions was not acceptable. The sample population could therefore reflect a similar proportion of fashion followers who, as in the Workman and Johnson study, demonstrated only a limited need for variety or unfamiliarity in fashion.

There is support for Kean's (1997) position that technology has compelled enterprising manufacturers and retailers to stimulate homogeneity in the consumer goods market. This sample population indicated that familiarity in terms of colour and silhouette had the biggest influence on their acceptance or purchase of MarketPlace's garments. Foreign manufacturers who expect success in the US market are therefore advised to blend the tastes and traditions of their culturally inspired designs carefully with standardised or widely accepted US products.

\section{Limitations}

This study represented a partial test of Rogers' (1962) diffusion theory in that only three of the five characteristics of innovation were explored. The focus of this study was purposely narrowed to examine only five design elements. Many additional elements such as price, fibre, hand, drape, content and construction quality may interact with perceptions of the five elements that were tested, perhaps yielding different results.
This study was somewhat limited by the quality of the slides as two-dimensional representations of the garments. Attempts were made to provide a clear, unstylised replication of each garment. However, the researchers could not control the conditions under which the slides were viewed. Some rooms may have had less light and greater colour clarity, and some groups may have been allowed longer exposure to each slide.

\section{Marketing applications}

There are several important implications in terms of the familiarity of garment attributes for the MarketPlace product development team. The manufacturer is encouraged to position its garments with due consideration of consumers' perceptions of currently favoured ideas in the same product categories (skirts and pants). Catalogue photographs should illustrate how these India-inspired garments may add newness to existing wardrobes by easy mixing and matching with acceptable garments. The ideal marketing strategy would focus on the characteristics of the garment that render it similar to, and yet different from, existing ideas.

In view of the finding that colour and silhouette were the two most influential characteristics in consumer acceptance, the colour palettes of MarketPlace's garments should perhaps reflect popular US colour palettes. Colour compatibility would undoubtedly increase a garment's integration in an existing wardrobe. The popular US silhouette should also be examined and reflected in MarketPlace's garments. Too much variation from the currently accepted silhouette, for example too wide or too short a pants leg, could limit a garment's acceptability. In other words, the designers of Market Place's garments should not deviate too much from existing US colour and silhouette ideals.

On the other hand garment owners did not appear to demand familiarity with the fabric, embellishment, fastener and construction methods. In terms of MarketPlace's artistic and employment philosophies, these findings suggest that the company's labour-intensive fabrications and embellishments are potential areas for continued experimentation with culturally inspired fabric and design motifs. In addition, the company's low technological status does not appear to have significantly influenced perceptions of construction and fastener acceptance. Though limited by export regulations, machinery, materials and employee skills, new MarketPlace skirt and pants designs could represent the critical balance between familiar and original garment elements while fostering artisan empowerment.

\section{CONCLUSION}

This research offered an opportunity for dialogue and collaboration between managers of an artisan enterprise in India and academic researchers in the US. 
The MarketPlace designers and artisans may ultimately select insights from research findings that accommodate their dual goals of developing a US market for their India-inspired apparel and fostering an organisational culture that values artisan empowerment. Stewart (1991:77) uses the concept of an "opportunity structure" to refer to the differential access of individuals in less-developed countries for accumulating knowledge and skills in a business system. In expanding MarketPlace's customer-based information, the researchers attempted to equalise the "opportunity structure" used by the company to make decisions.

\section{REFERENCES}

AAGESON, TH. 1997. Investing in the artisan sector. Paper presented at the International Symposium on Crafts and the International Market: Trade and Customs Codification. United Nations Educational, Scientific and Cultural Organisation, Manila, October 6-8.

ABRAHAM-MURALI, L \& LITTRELL, MA. 1995. Consumers' conceptualization of apparel attributes. Clothing and Textiles Research Journal 13(2):65-74.

BARNETT, HG. 1953. Innovation: the basis for cultural change. New York. McGraw-Hill.

BASS, FM \& KING, CW. 1968. The theory of first purchase of new products, in Cox, K \& Ellis, B (eds). 1968. New measures of responsibility for marketing. American Marketing Association Conference Proceedings, 27 June:263-272.

BASU, K. 1995. Marketing developing society crafts: a framework for analysis and change, in Costa, JA and Bamossy, GJ (eds). 1995. Marketing in a multicultural world. Thousand Oaks, Cal. Sage.

BEHLING, DU. 1992. Three and a half decades of fashion adoption research: what have we learned? Clothing and Textiles Research Journal 10(2):34-41.

BERG, SV. (1973. Interdependent tastes and fashion behavior. The Quarterly Review of Economics and Business 13 (2):49-58.

BULL, R. 1975. Psychology, clothing and fashion: a review. Bulletin of the British Psychological Society 28:459-465.

CHOWDHARY, U \& DICKEY, L. 1988. Fashion opinion leadership and media exposure among college women in India. Home Economics Research Journal 16:183-194.

DELONG, M, KIM, S \& LARNTZ, K. 1993. Perceptions of garment proportions by female observers. Perceptual and Motor Skills 76:811-819.

DICKSON, MA \& LITTRELL, MA. 1997. Consumers of clothing from alternative trading organizations: societal attitudes and purchase evaluative criteria. Clothing and Textiles Research Journal 15(1):20-33.

ECKMAN, M. 1997. Attractiveness of men's suits: the effect of aesthetic attributes and consumer characteristics. Clothing and Textiles Research Journal 15(4):193-202.

FORSYTHE, S, BUTLER, S \& KIM, MS. 1991. Fashion adoption: theory and pragmatics. Clothing and Textiles Research Journal 9(4):8-15.

GRINDERENG, MP. 1967. Fashion diffusion. Journal of Home Economics 59(3):171-174.

GOLDSMITH, RE, FLYNN, L \& MOORE, MA. 1996. The self-concept of fashion leaders. Clothing and Textiles Research Journal 14(4):242-248.

HERALD, J. 1992. World crafts. London. Letts.

HOLBROOK, MB. 1983. On the importance of using real products in research on merchandising strategy. Journal of Retailing 59(Spring):4-20.

HOWARD, JA \& SHETH, JN. 1969. The theory of buyer behavior. New York. Wiley.
HURLOCK, E. 1929. The psychology of dress. New York. Ronald.

KAISER, SB, NAGASAWA, RH \& HUTTON, SS. 1995. Construction of an SI theory of fashion. Part 1: ambivalence and change. Clothing and Textiles Research Journal 13(3):172183.

KATZ, E, LEVIN, ML \& HAMILTON, H. 1963. Traditions of research on the diffusion of innovation. American Sociological Review 28:237-252.

KEAN, RC. 1997. The role of the fashion system in fashion change: a response to the Kaiser, Nagasawa and Hutton model. Clothing and Textiles Research Journal 15(3):172177.

KING, CW. 1965. Communicating with the innovator in the fashion adoption process. Institute for Research in the Behavioral, Economic and Management Sciences, Herman C Krannert Graduate School of Industrial Administration, Purdue University. Paper 121.

KING, CW \& BAUMGARTEN, SA. 1970. Fashion adoption among college students: a project overview. Institute for Research in the Behavioral, Economic and Management Sciences, Purdue University. Paper 292.

LENNON, SJ \& BURNS, LD. 1993. Charting our directions: patterns for the future, in Lennon, SJ \& Burns, LD (eds). 1993. Social science aspects of dress: new directions. ITAA Special Publication 5. Monument, Col. International Textiles and Apparel Association.

LIONBERGER, HL. 1960. Adoption of new ideas and practices: a summary of research dealing with the acceptance of technology change in agriculture with implications in facilitating social change. Ames, la. lowa State University Press. LITTRELL, MA \& DICKSON, MA. 1998. Fair trade performance in a competitive market. Clothing and Textiles Research Journal 16(4):176-189.

LITTRELL, MA \& DICKSON, MA. 1999. Social responsibility in the global market: fair trade of cultural products. Thousand Oaks, Cal. Sage.

MAHAJAN, V \& PETERSON, RA. 1985. Models for innovation diffusion. Sage University Paper Series on Quantitative Applications in the Social Sciences, 07-048. Beverly Hills, Cal. Sage.

MASON, JB \& BELLENGER, D. 1973-74. Analyzing high fashion acceptance. Journal of Retailing 49(4):79-96.

MIKKELSON, LH, GOLDMARK, L \& HAGEN-WOOD, M. 1997. IDB support to the handicrafts sector 1965-2001. Washington, DC. Inter-American Development Bank.

MINSHALL, BC. 1994. Apparel preferences: underlying dimensions and measurement, in DeLong, MR \& Fiore, AM (eds). Aesthetics of textiles and clothing: advancing multidisciplinary perspectives. ITAA Special Publication 7. Monument, Col. International Textiles and Apparel Association.

MORRIS, WF (Jr). 1996. Handmade money: Latin American artisans in the marketplace. Washington, DC. Organisation of American States.

NASH, J. 1993. Introduction: traditional arts and changing markets in Middle America, in Nash, J. Crafts in the world market. Albany, NY. State University of New York Press.

PAGE-REEVES, J. 1998. Alpaca sweater design and marketing: problems and prospects for cooperative knitting organizations in Bolivia. Human Organization 57(1):83-93.

PETERSON, RA \& MAHAJAN, V. 1978. Multi-product growth models, in Sheth, J. Research in Marketing. Greenwich, Conn. JAI Press.

ROBINSON, TS. 1967. The process of innovation and the diffusion of innovation. Journal of Marketing 31 (January):1419.

ROGERS, EM. 1995. Diffusion of innovations. 4th ed. New York. Free Press.

ROGERS, EM. 1962. Diffusion of innovations. 1st ed. New York. Free Press.

SPROLES, GB.1979. Fashion: consumer behavior toward dress. Minneapolis, Minn. Burgess. 
SPROLES, GB \& KING, CW. 1973. The consumer fashion change agent: a theoretical conceptualization and empirical identification. Institute for Research in the Behavioral, Economic and Management Sciences, Purdue University, Paper 433

STEWART, A. 1991. A prospectus on the anthropology of entrepreneurship. Entrepreneurship Theory and Practice 16 (2):71-92.

SUMMERS, JO. 1970. The identity of women's clothing fashion opinion leaders. Journal of Marketing Research 7:178-185.

TICE, KE. 1995. Kuna crafts, gender and the global econ- omy. Austin, Tex. University of Texas Press.

USHER, AP. 1954. A history of mechanical inventions. Cambridge, Mass. Harvard University Press.

WHISNEY, AJ, WINAKOR, G \& WOLINS, L. 1979. Fashion preference: drawings versus photographs. Home Economics Research Journal 8(2):138-150.

WINAKOR, G \& GOINGS, BD. 1973. Fashion preference: measurement of change. Home Economics Research Journal 1(3):195-209.

WORKMAN, JE \& JOHNSON, KKP. 1993. Fashion opinion leadership, fashion innovativeness, and need for variety. Clothing and Textiles Research Journal 11(3):60-64. 